Check for updates

Montreal, Canada

Cite this as: BMJ 2021;374:n1856 http://dx.doi.org/10.1136/bmi.n1856 Published: 21 July 2021

\title{
Covid-19: Two thirds in India carry antibodies, while research suggests country's death toll is 10 times official figure
}

Owen Dyer

India's fourth "serosurvey" of the covid pandemic has found neutralising antibodies to the novel coronavirus in $67.6 \%$ of people aged over 6 , suggesting that more than two in three people have already been exposed to the virus or a vaccine. ${ }^{1}$

The survey, conducted in the last 10 days of June and the first week of July, indicates the scale of the punishing second wave that hit the country in May. The previous survey, done in December and January, found seropositivity in only $24.1 \%$ of people tested.

Some of the antibodies detected were due to vaccination rather than infection. India had administered about 300 million doses before the latest survey. The pace has since quickened, and 412 million doses have been given as of 21 July.

About 400 million people remain highly susceptible to the virus, warned Balram Bhargava, director of the Indian Council of Medical Research, which conducted the survey. The distribution of antibodies was geographically uneven, he said, leaving pockets of greater vulnerability around the country. Women and city dwellers had slightly more antibodies than average. The most seropositive age group was people aged $45-60$, of whom $77.6 \%$ had antibodies. The least seropositive group was children aged 6-9, of whom $57.2 \%$ had antibodies.

\section{Measuring deaths}

The findings seem to broadly concur with those of a seropositivity survey conducted from March to June this year by the World Health Organization and the All India Institute of Medical Sciences, which found $55.7 \%$ seropositivity in children and $63.5 \%$ in adults. ${ }^{2}$

The results will also lend support to researchers who this week argued that India's official figures understated its true pandemic death toll by an "order of magnitude.” Their analysis, published in the Indian Express, concluded that about four million people had died from covid-19 in India. The official figure stands at 418511 deaths. ${ }^{3}$

The researchers looked at three measuring systems. The first was excess mortality in the civil death registration systems of Indian states, several of which had recently updated figures. This led to an estimate of two million excess deaths in the first wave (to March 2021) and 1.4 million in the second. But, the researchers warned, this system undercounts deaths even in normal years.

The second estimate was based on June's WHO-AIIMS seropositivity survey (the latest survey by the Indian Council of Medical Research was not yet available) and calculated likely deaths by applying international infection fatality rates estimated by the US Centers for Disease Control, stratified by age. The resulting estimates were 1.5 million deaths in the first wave and 2.4 million in the second.

The third estimate was based on the Consumer Pyramid Household Survey conducted by the Center for the Monitoring of India's Economy in June, near the end of the second wave. It asked whether anyone in the household had died in the past four months. The answers led the researchers to estimate 3.4 million excess deaths in the first wave and 1.5 million in the second.

\section{Gentler wave}

"These numbers are far from definitive," the authors concede. But roughly four million deaths would correspond to a fatality rate of about $0.5 \%$ if the seropositivity survey is correct in estimating about 800 million infections. The official death count, by contrast, would suggest an implausibly low fatality rate of $0.05 \%$.

The first wave was deadlier than most people think, the researchers argue, but the second wave was more acutely felt because it was compressed into a few weeks, overloading hospitals and oxygen supplies.

But the seropositivity survey offers hope of a gentler third wave throughout most of India as the country's $\mathrm{R}$ number starts to tick upward again, reaching 0.95 on 20 July.

Of the people surveyed, $62.2 \%$ had no vaccination, $24.8 \%$ had had one dose, and $13 \%$ were fully vaccinated. Seropositivity was $81 \%$ among people who had received one vaccine dose and $89.8 \%$ among those who had had both. Among health workers, $10.5 \%$ were unvaccinated and seropositivity was $85.2 \%$.

1 Anand A, Sandefur J, Subramanian A. Three new estimates of deaths in India during the pandemic. Center for Global Development. 20 Jul 2021. https://www.cgdev.org/blog/three-new-estimates-deaths-during-pandemic 2 WHO-AllMS seroprevalence survey outcome "positive"; larger nationwide sample size needed for comprehensive results: Guleria. Times of India2021 Jun 18. https://timesofindia.indiatimes.com/india/who-aiims-seroprevalencesurvey-outcome-positive-larger-nationwide-sample-size-needed-for-comprehensive-results-guleria/articleshow/83630667.cms

3 Anand A, Sandefur J, Subramanian A. Why we need to count the Covid dead. Indian Express 2021 Jul 20. https://indianexpress.com/article/opinion/columns/india-covid-deaths-second-wave-7412619/

This article is made freely available for use in accordance with BMJ's website terms and conditions for the duration of the covid-19 pandemic or until otherwise determined by BMJ. You may use, download and print the article for any lawful, non-commercial purpose (including text and data mining) provided that all copyright notices and trade marks are retained. 